\author{
I. I. Mechnikov Odesa National University \\ e-mail:nitsuk@onu.edu.ua
}

\title{
OPTICAL PROPERTIES OF OF ZNS:FE NANOCHRYSTALLS OBTAINED BY COLLOIDAL METHOD
}

\begin{abstract}
Iron doped zinc sulfide nanocrystals were obtained by colloidal synthesis using gelatin, lactose or polyvinyl alcohol as a stabilizing matrix. The structure of the nanocrystals was determined using X-ray diffraction (XRD). The influence of the concentration effect on the size and properties of $\mathrm{ZnS}$ nanocrystals, the optical absorption spectra and photoluminescence spectra were studied, and the types of optical transitions in these nanocrystals were determined.
\end{abstract}

\section{Introduction}

In recent years, researchers' interest in colloidal methods for the synthesis of semiconductor nanoparticles has been growing. These particles have a number of unique characteristics determined by their shape and size. In this regard, the widespread practical use of nanoparticles is constrained by the possibility of obtaining nanoparticles with a controlled shape and size.

Among II-VI semiconductor compounds, zinc sulfide has the largest band gap. Another more important advantage of $\mathrm{ZnS}$ is non-toxicity, which makes the use of $\mathrm{ZnS}$ nanocrystals as luminescent markers in medicine promising $[1,2]$. The radiation of such markers should be localized in the area of maximum transparency of living tissues $(0.65-1.5 \mu \mathrm{m})$. Our studies on semiconductor ZnS:Fe single crystals [3] indicate the presence of broad absorption bands and photoluminescence $(0.5-0.8 \mu \mathrm{m})$ that are effectively excited by light from the impurity absorption region.

The purpose of this work is to develop a technique for obtaining $\mathrm{ZnS}: \mathrm{Fe}$ nanocrystals in which the spectra of optical absorption and photoluminescence are in the near infrared region. To determine the nature of the optical and radiation transitions, the results of the study of the optical properties of $\mathrm{ZnS}$ : Fe single crystals are given.

\section{Experimental}

$\mathrm{ZnS}, \mathrm{ZnS}$ : Fe nanocrystals were obtained by chemical synthesis in a matrix of polyvinyl alcohol, gelatin or lactose. Pure zinc sulphide nanocrystals were obtained by reaction of:

$$
\mathrm{ZnCl}+\mathrm{Na}_{2} \mathrm{~S} \rightarrow \mathrm{ZnS}+2 \mathrm{NaCl} \text {. }
$$

Fe doped $\mathrm{ZnS}$ nanocrystals were obtained by reaction of:

$$
\begin{aligned}
\mathrm{ZnCl}_{2}+\mathrm{Na}_{2} \mathrm{~S} & +\mathrm{Fe}_{2} \mathrm{Cl}_{3} \rightarrow \mathrm{ZnS}: \mathrm{Fe}: \mathrm{Cl}+ \\
& +2 \mathrm{NaCl}+\mathrm{Cl}_{2} \uparrow .
\end{aligned}
$$

Commercial reagents from Beijing were used for the synthesis.

After synthesis, the solution was dried on a quartz or glass substrate. As a result, $\mathrm{ZnS}, \mathrm{ZnS}$ :Fe nanocrystals were obtained in a transparent solid polymer matrix. The structure analysis of the obtained ZnS nanoparticles was carried out by $\mathrm{X}$-ray diffraction (Fig. 1). The diffraction peaks $2 \theta$ correspond to the plane (111) in zinc sulfide.

\section{Experiment and results}

The optical absorption spectra of undoped nanocrystals are shown in Fig. 2, curve 1. The band gap of zinc sulfide single crystals is $3.6 \mathrm{eV}$. The nanocrystals obtained are characterized by bandgap values $E_{g}$ of $5.07 \mathrm{eV}$ at $\mathrm{Na}_{2} \mathrm{~S}$ and $\mathrm{ZnCl}_{2}$ concentrations of $10 \%$, respectively.

The optical absorption spectra of $\mathrm{ZnS}: \mathrm{Fe}$ nanocrystals show an offset of the absorption edge towards lower energies compared to undoped samples (Fig. 2, curves 2-4). The magnitude of the shift is $0.2 \mathrm{eV}$ with increasing 
$\mathrm{Fe}_{2} \mathrm{Cl}_{3}$ concentration from 0.1 to $0.5 \%$, this may be due to an increase in the Fe content in the samples, or an increase in the size of the nanocrystals.

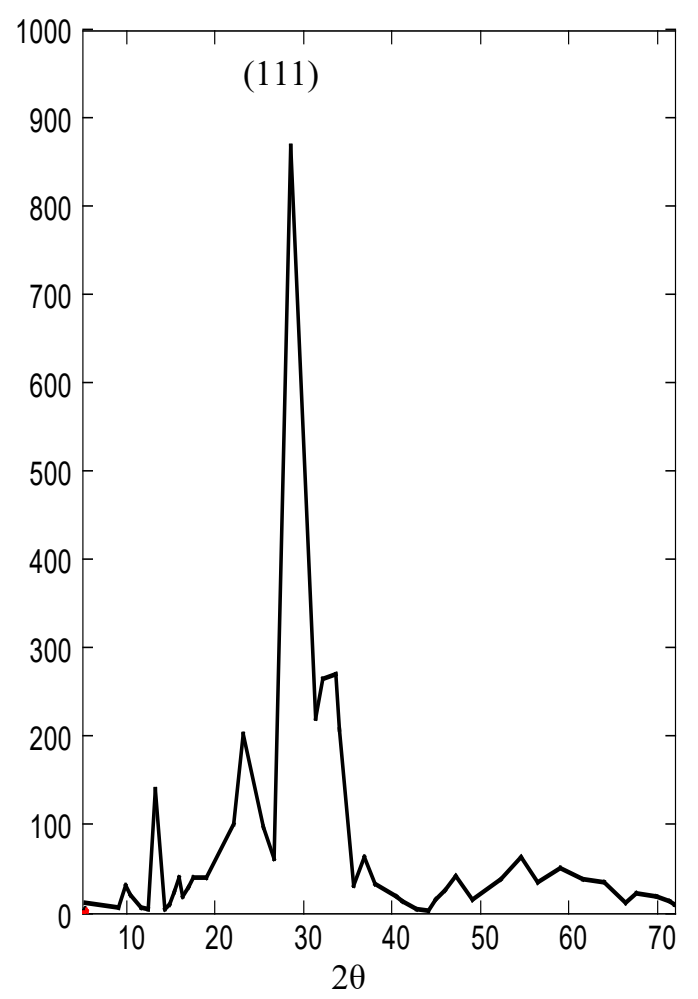

Fig. 1. XRD-pattern of ZnS:Fe nanocrystals.

The size of nanocrystals was estimated by the difference of their bandgap and bulk single crystals using the ratio [4]:

$$
R=\frac{h}{\sqrt{8 \mu \Delta E_{g}}},
$$

$h$ - Planck constant, $\mu=\left(\left(m_{e}\right)^{-1}+\left(m_{h}\right)^{-1}\right)^{-1}-$ reduced mass, $m_{e}=0.27 m_{0}, \quad m_{h}=0.58 m_{0}$, respectively, the effective masses of electrons and holes in zinc sulfide, $m_{0}-$ mass of free electron, $\Delta E_{g}$ - the difference between the bandgap of the nanocrystals $(3.63 \mathrm{eV})$. As shown in the Table 1 , the size of the nanocrystallites does not change significantly.

The optical absorption spectra of $\mathrm{ZnS}: \mathrm{Fe}$ nanocrystals in the region of $1.6-4.0 \mathrm{eV}$ are characterized by the presence of a considerable number of absorption lines (Fig. 3). Increasing the concentration of Fe leads to an increase in the absorption in this region with the unchanged arrangement of the maxima of the absorption lines. This indicates the intracenter nature of the absorption lines in ZnS:Fe nanocrystals. Similar absorption lines were observed previously in bulk ZnS:Fe crystals [3].

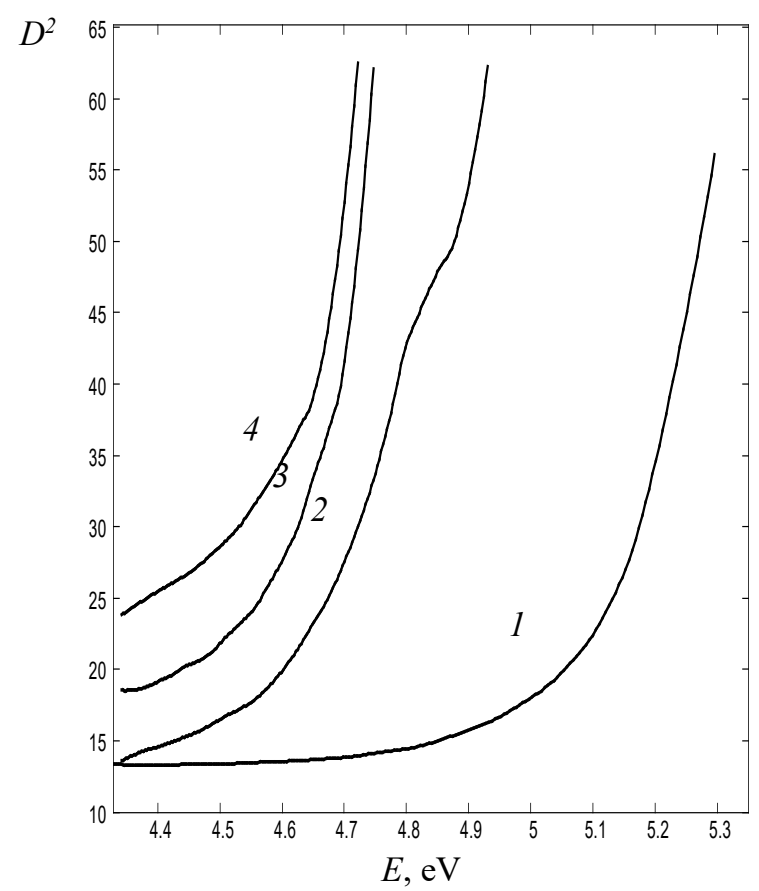

Fig.2 Optical absorption spectra of $\mathrm{ZnS}$ (1), ZnS:Fe(24) nanocrystals, $T=300 \mathrm{~K}$.

Table 2 summarizes the energies and interpretation of optical transitions in bulk and $\mathrm{ZnS}$ :Fe nanocrystals. The middle column shows the calculations of the energy states of $\mathrm{Fe}^{2+}$ ions in the approximation of the nearest tetrahedral environment at the crystal field parameters $\Delta=$ $3500 \mathrm{~cm}^{-1}$ and $\mathrm{B}=600 \mathrm{~cm}^{-1}$. In this case, light absorption occurs through optical transitions from the ground ${ }^{5} E(D)$ to the excited states of the $\mathrm{Fe}^{2+}$ ion. As shown in Table 2, the calculations are equally good for both bulk and nanocrystals, which testifies to the validity of the crystal field theory, according to which the ions of transition elements are affected by the closest tetrahedral environment whose size is smaller than the size of the 
Table 2. Optical transitions involving $\mathrm{Fe}^{2+}$ ions

\begin{tabular}{|c|c|c|c|c|c|c|}
\hline № & Type of crystal & \multicolumn{2}{|c|}{ ZnS:Fe bulk } & \multirow{2}{*}{$\frac{\text { Culc }}{E_{\text {culc.abs., }} \mathrm{eV}}$} & \multicolumn{2}{|c|}{ ZnS:Fe nano } \\
\hline & Transition & $\mathrm{E}_{\text {exp. abs., }} \mathrm{eV}$ & $E_{P L,} e V$ & & $E_{\text {exp. abs., }} \mathrm{eV}$ & $E_{P L,} e V$ \\
\hline 1 & ${ }^{5} E(D) \rightleftarrows{ }^{I} T_{2}(F)$ & --- & --- & --- & 3.87 & --- \\
\hline 2 & ${ }^{5} E(D) \rightleftarrows{ }^{I} T_{2}(F)$ & --- & --- & --- & 3.84 & --- \\
\hline 3 & ${ }^{5} E(D) \rightleftarrows{ }^{1} A_{2}(F)$ & --- & --- & --- & 3.72 & --- \\
\hline 4 & ${ }^{5} E(D) \rightleftarrows{ }^{1} A_{1}(S)$ & --- & --- & --- & 3.66 & --- \\
\hline 5 & ${ }^{5} E(D) \rightleftarrows{ }^{1} T_{2}(D)$ & --- & --- & --- & 3.48 & --- \\
\hline 6 & ${ }^{5} E(D) \rightleftarrows{ }^{1} T_{1}(G)$ & --- & --- & 3.34 & 3.37 & --- \\
\hline 7 & ${ }^{5} E(D) \rightleftarrows{ }^{1} E(D)$ & --- & --- & 3.22 & 3.21 & --- \\
\hline 8 & ${ }^{5} E(D) \rightleftarrows{ }^{I} A_{1}(G)$ & 3.18 & --- & 3.19 & 3.14 & --- \\
\hline 9 & ${ }^{5} E(D) \rightleftarrows{ }^{I} E(G)$ & 3.06 & --- & 3.06 & 3.05 & --- \\
\hline 10 & ${ }^{5} E(D) \rightleftarrows{ }^{l} T_{2}(G)$ & 2.94 & --- & 2.97 & 2.97 & --- \\
\hline 11 & ${ }^{5} E(D) \rightleftarrows{ }^{3} T_{2}(D)$ & 2.84 & --- & 2.82 & 2.84 & --- \\
\hline 12 & ${ }^{5} E(D) \rightleftarrows{ }^{3} E(D)$ & 2.78 & --- & 2.75 & 2.78 & --- \\
\hline 13 & ${ }^{5} E(D) \rightleftarrows{ }^{I} T_{l}(I)$ & 2.72 & 2.7 & 2.72 & 2.7 & --- \\
\hline 14 & ${ }^{5} E(D) \rightleftarrows{ }^{I} T_{2}(I)$ & --- & --- & 2.65 & 2.65 & --- \\
\hline 15 & ${ }^{5} E(D) \rightleftarrows{ }^{1} A_{1}(I)$ & --- & 2.58 & 2.64 & 2.62 & --- \\
\hline 16 & ${ }^{5} E(D) \rightleftarrows{ }^{3} T_{1}(P)$ & 2.60 & --- & 2.60 & 2.58 & 2.55 \\
\hline 17 & ${ }^{5} E(D) \rightleftarrows{ }^{3} T_{2}(G)$ & --- & 2.48 & 2.52 & 2.50 & 2.47 \\
\hline 18 & ${ }^{5} E(D) \rightleftarrows{ }^{I} A_{2}(I)$ & 2.50 & 2.36 & 2.51 & 2.45 & --- \\
\hline 19 & ${ }^{5} E(D) \rightleftarrows{ }^{3} T_{l}(G)$ & 2.39 & 2.28 & 2.38 & 2.41 & --- \\
\hline 20 & ${ }^{5} E(D) \rightleftarrows{ }^{I} T_{2}(I)$ & 2.30 & 2.25 & 2.34 & 2.38 & 2.31 \\
\hline 21 & ${ }^{5} E(D) \rightleftarrows{ }^{l} E(I)$ & --- & --- & 2.33 & 2.33 & --- \\
\hline 22 & ${ }^{5} E(D) \rightleftarrows{ }^{3} T_{2}(F)$ & --- & 2.20 & 2.24 & 2.26 & 2.25 \\
\hline 23 & ${ }^{5} E(D) \rightleftarrows{ }^{3} E(G)$ & 2.22 & 2.09 & 2.23 & 2.18 & 2.17 \\
\hline 24 & ${ }^{5} E(D) \rightleftarrows{ }^{3} T_{l}(F)$ & 2.11 & 1.99 & 2.08 & 2.07 & 2.05 \\
\hline 25 & ${ }^{5} E(D) \rightleftarrows{ }^{3} A_{1}(G)$ & 2.03 & 1.88 & 2.03 & 2.0 & --- \\
\hline 26 & ${ }^{5} E(D) \rightleftarrows{ }^{3} A_{2}(F)$ & 1.94 & --- & 1.97 & 1.91 & 1.91 \\
\hline 27 & ${ }^{5} E(D) \rightleftarrows{ }^{3} T_{2}(H)$ & 1.85 & --- & 1.84 & 1.84 & 1.83 \\
\hline 28 & ${ }^{5} E(D) \rightleftarrows{ }^{3} T_{l}(H)$ & 1.82 & --- & 1.82 & 1.77 & 1.75 \\
\hline 29 & ${ }^{5} E(D) \rightleftarrows{ }^{3} E(H)$ & 1.75 & --- & 1.73 & 1.71 & --- \\
\hline 30 & ${ }^{5} E(D) \rightleftarrows{ }^{3} T_{1}(H)$ & 1.35 & 1.30 & 1.37 & --- & --- \\
\hline 31 & ${ }^{5} E(D) \rightleftarrows{ }^{5} T_{2}(D)$ & 0.45 & 0.68 & 0.45 & -- & --- \\
\hline
\end{tabular}

nanocrystallites (lattice period) $\mathrm{ZnS}$ is $5.6 \AA ̊$ and nanocrystallite size is $3-5 \mathrm{~nm}$ ).

Photoluminescence of the undoped $\mathrm{ZnS}$ nanocrystals wasn't observed in the region of 1.6$3.5 \mathrm{eV}$. The doping of $\mathrm{ZnS}$ nanocrystals leads to the formation of a broad structured photoluminescence band in the $1.6-2.8 \mathrm{eV}$ region (Fig. 4). The same structured photoluminescence bands were observed previously in bulk $\mathrm{ZnS}: \mathrm{Fe}$ crystals. With increasing $\mathrm{Fe}$ concentrations, the luminescence spectrum expands toward lower energies. 


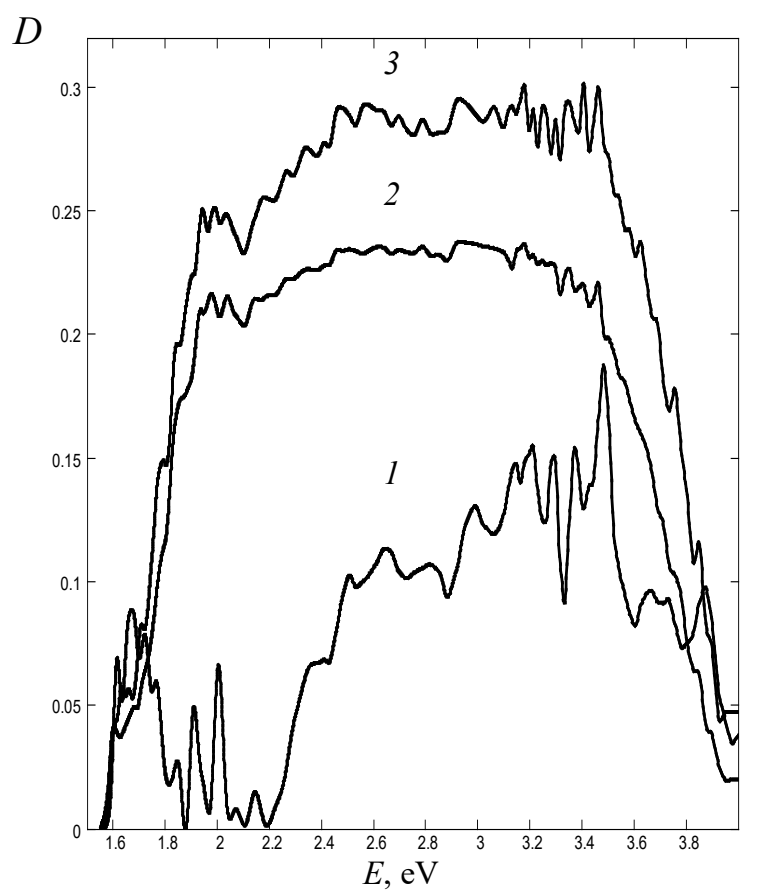

Fig.3. Optical density spectra of $\mathrm{ZnS}: \mathrm{Fe}$ nanocrystals. $[\mathrm{Fe}]=0.1(1), 0.3(2), 0.5 \%(3) . T=300 \mathrm{~K}$.

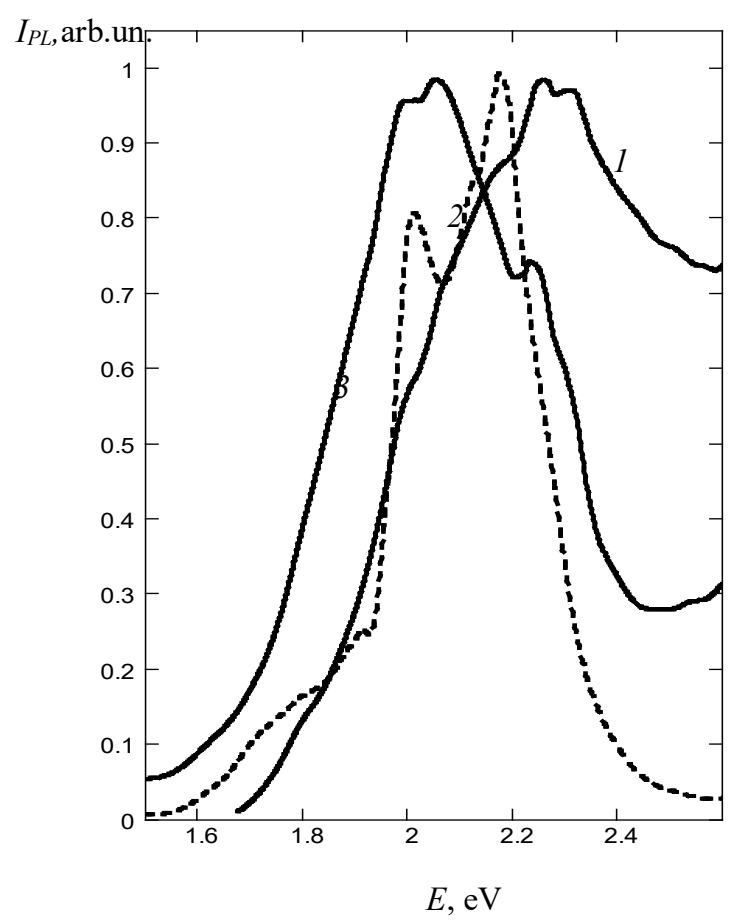

Fig.4. Photoluminescence spectra of $\mathrm{ZnS}: \mathrm{Fe}$ nanocrystals. $[\mathrm{Fe}]=0.1(1), 0.3(2)$ та $0.5 \%(3) . \mathrm{T}=300$ K.

\section{Conclusions}

Iron-doped zinc sulfide nanocrystals were obtained. A comparative analysis of the optical absorption and photoluminescence spectra of iron-doped zinc sulfide nano- and single crystals was performed.

The nature of intracenter optical transitions that determine the optical properties of $\mathrm{ZnS}$ : Fe nanocrystals is established. The crystal field theory that the splitting of the energy states of $\mathrm{Fe}^{2+}$ ions occurs under the action of the closest tetrahedral environment is confirmed.

$\mathrm{ZnS}$ : Fe nanocrystals have a photoluminescence spectrum corresponding to the transparency of living tissues. This allows the use of $\mathrm{ZnS}$ : Fe nanocrystals as fluorescent markers in medical diagnostics

\section{References}

1. Rosdi I., Saleh M-H., Norsal K., Malek M. Z.- A., Sulaiman M. - A. and Baharom M. -A. Synthesis of $\mathrm{Fe}^{2+}$ ion Doped ZnS Nanoparticles // Advanced Materials Research. - 2014. - V. 879. - P.155-163.

2. Kumar S., Singhal M., Sharma J. K. Functionalization and characterization of $\mathrm{ZnS}$ quantum dots using biocompatible L - cysteine// J. Mater Sci: Mater Electron. - 2013. - V. 24. P.3875-3880.

3. Nitsuk Yu.A., Vaksman Yu.F., Yatsun V.V., Purtov Yu.N. Optical absorption and diffusion of iron in $\mathrm{ZnS}$ single crystals// Functional Materials. - 2012. - V.19, No.2.- P.182-186.
4.
Гусев
А.И.,
Ремпель
A.A.

Нанокристаллические материалы.М:Физматлит.-2000.-С.224. 
Yu. A. Nitsuk, Yu. F. Vaksman, I. V. Tepliakova, V. A. SMyntyna, G. V. Korenkova, Ie. V. Brytavskyi

\author{
I. I. Mechnikov Odesa National University \\ e-mail: nitsuk@onu.edu.ua
}

\title{
OPTICAL PROPERTIES OF OF ZnS:Fe NANOCHRYSTALLS OBTAINED BY COLLOIDAL METHOD
}

\begin{abstract}
- iron doped zinc sulfide nanocrystals were obtained by colloidal synthesis using gelatin, lactose or polyvinyl alcohol as a stabilizing matrix. The structure of the nanocrystals was determined using X-ray diffraction (XRD). The influence of the concentration effect on the size and properties of $\mathrm{ZnS}$ nanocrystals, the optical absorption spectra and photoluminescence spectra were studied, and the types of optical transitions in these nanocrystals were determined.
\end{abstract}

Key words - Zinc Sulfide, Nanocrystals, Absorption Edge, Photoluminescence.

УДК 621.315 .592

Ю. А. Ніиук, Ю. Ф. Ваксман, І. В. Теплякова, В. А. Сминтина, Г. В. Коренкова, С. В. Бритавський

Одеський національний університет імені I. I. Мечникова e-mail: nitsuk@onu.edu.ua

\section{ОПТИЧНІВЛАСТИВОСТІНАНОКРИСТАЛІВZnS:FеОТРИМАНИХКОЛОЇДНИМ МЕТОДОМ}

Анотація- Нанокристали сульфіду цинку легованого залізом були отримані шляхом колоїдного синтезу з використанням желатину, лактози або полівінілового спирту в якості стабілізуючої матриці. Структура нанокристалів визначена за допомогою рентгенівської дифракції (XRD). Вивчено вплив концентраційного ефекту на розмір і властивості нанокристалів ZnS, спектри оптичного поглинання і фотолюмінесценції, визначено типи оптичних переходів в даних нанокристалах.

Ключові слова - Сульфід цинку, нанокристали, край поглинання, фотолюмінесценція. 
Ю. А. Нииук, Ю. Ф. Ваксман, И. В. Теплякова, В. А. Смынтына, А. В. Коренкова,

Е. В. Бритавский

Одесский национальний университет имени И. И. Мечникова

e-mail: nitsuk@onu.edu.ua

\section{ОПТИЧЕСКИЕ СВОЙСТВА НАНОКРИСТАЛЛОВ ZnS:Fe ПОЛУЧЕННЫХ КОЛЛОИДНЫМ МЕТОДОМ}

Аннотация - Нанокристаллы сульфида цинка легированного железом были получены путем коллоидного синтеза с использованием желатина, лактозы или поливинилового спирта в качестве стабилизирующей матрицы. Структура нанокристаллов определена при помощи рентгеновской дифракции (XRD). Изучены влияние концентрационного эффекта на размер и свойства нанокристаллов $\mathrm{ZnS}$, спектры оптического поглощения и фотолюминесценции, определены типы оптических переходов в данных нанокристаллах.

Ключевые слова - Сульфид цинка, нанокристаллы, край поглощения, фотолюминесценция. 